\title{
Comparison of two Agricultural Wastes for Phenol Removal Via Peroxidase-Catalyzed Enzymatic Approach
}

\author{
Tung Chiong ${ }^{1,2}$, Ee H. Khor ${ }^{1}$, Michael K. Danquah ${ }^{1}$ and Sie Y. Lau ${ }^{1}$ \\ ${ }^{1}$ Department of Chemical Engineering, Curtin University Sarawak, Malaysia \\ ${ }^{2}$ Curtin Sarawak Research Institute, Curtin University Sarawak, Malaysia
}

\begin{abstract}
Agricultural wastes of jicama and luffa skin peels were used as the source for peroxidase extraction. The extracted crude enzymes showed similar activities, $1.34 \mathrm{U} / \mathrm{mL}$ and $1.22 \mathrm{U} / \mathrm{mL}$ for jicama and luffa peroxidase respectively. These peroxidases were used to treat phenol under varying operating conditions of buffer $\mathrm{pH}$, hydrogen peroxide concentration, enzyme volume and temperature. Jicama peroxidase demonstrated a phenol removal efficiency of approximately $90 \%$ at buffer $\mathrm{pH} 7,1 \mathrm{mM}$ hydrogen peroxide using $1.5 \mathrm{~mL}$ enzyme at $25^{\circ} \mathrm{C}$. Luffa peroxidase required a higher dosage of hydrogen peroxide, and exhibited a removal efficiency of $84 \%$ at $8 \mathrm{mM}$ with other operating conditions same as jicama peroxidase. Jicama peroxidase is sensitive to $\mathrm{pH}$ change and more susceptible to thermal denaturation. Luffa peroxidase showed a better stability in terms of temperature.
\end{abstract}

\section{Introduction}

Phenol and its derivatives are present in various industrial effluents such as petroleum refineries, coal conversion, pulp and paper, resins and textiles. Phenolic compounds are mostly toxic and have been classified as hazardous pollutants [1], because they are harmful to microorganisms even at low concentrations. Therefore, these phenol-containing industrial effluents must be properly treated before they can be discharged into the receiving water bodies.

Conventional treatment methods for phenolcontaining wastewater are generally microbial degradation [2], adsorption on activated carbon [3], and chemical oxidation such as ozonation [4] and Fenton reaction [5]. Although these methods are able to show high phenol removal efficiencies, some common drawbacks have been encountered. These include lengthy start-up procedure for microbial acclimatization [6], microbial growth inhibition due to high concentrations of phenolic compounds [7], intensive cost and energy for carbon regeneration [8], and disposal concern of reagents used during reaction process [8]. Due to the shortcomings of these conventional methods, enzymatic approach has emerged as an alternative for phenol removal from wastewaters, owing to its advantages which include low energy requirements, operation over a wide range of conditions, ease of process control, and minimal environmental impact [9].

The removal of phenols and other aromatic compounds from aqueous solution via peroxidase in the presence of hydrogen peroxide was first reported by Klibanov et al. [10]. Since then, horseradish peroxidase
(HRP) became the most explored plant peroxidase, and its ability in removing various phenolic compounds from aqueous solutions are well documented [11]-[13]. Peroxidases from other sources such as soybean seed hulls, bitter gourd, cauliflower, potato and white radish have also been evaluated for their performances in treating phenol, and the reported results were encouraging [14]-[17].

It is notwithstanding that most of the plant peroxidases being studied are extracted from the edible parts of the plants, except soybean seed hulls. This will eventually cause competition with human food intake if the peroxidase extraction process is to be scaled-up to large capacity treatment. Hence, the present work aims to evaluate the performance of peroxidases extracted from agricultural wastes for phenol removal. Peroxidases were extracted from the skin peels of two locally available plants, such as jicama and luffa, which are non-edible and generally being discarded during food preparation. The performances of both crude enzyme extracts in phenol removal process were assessed and compared under varying reaction conditions.

\section{Materials and methods}

\subsection{Extraction of peroxidase}

Jicama and luffa purchased from local vegetable market were thoroughly washed with distilled water before their respective skin was peeled off. $100 \mathrm{~g}$ of jicama and luffa skin peels was respectively blended with $200 \mathrm{~mL}$ of $0.1 \mathrm{M}$ sodium carbonate buffer $\mathrm{pH} 10$ for $30 \mathrm{~s}$, and then 
homogenized for $30 \mathrm{~min}$ with constant stirring. The enzyme extract was then filtered through four layers of cheesecloth before being subjected to centrifugation at $4000 \mathrm{rpm}$ at $4^{\circ} \mathrm{C}$. The supernatant (crude extract) collected was sonicated and stored at $4^{\circ} \mathrm{C}$ until further use.

\subsection{Batch treatment of aqueous phenol solution}

The removal reaction was carried out by treating $1 \mathrm{mM}$ phenol solution with various dosages of enzyme volume in different buffer solutions. The enzymatic reaction was initiated by the addition of hydrogen peroxide $\left(\mathrm{H}_{2} \mathrm{O}_{2}\right)$ into the reaction mixture, and the mixture was incubated for $24 \mathrm{~h}$ with constant shaking to ensure maximum phenol removal. The efficiency of luffa and jicama peroxidases was studied in relation to the changes of $\mathrm{pH}$ of buffer solutions, $\mathrm{H}_{2} \mathrm{O}_{2}$ concentration, enzyme volume and temperature. The percentage of phenol removal was calculated based on equation (1).

$$
\text { Phenol removal }(\%)=\frac{C_{i}-C_{f}}{C_{i}} \times 100 \%
$$

$\mathrm{C}_{\mathrm{i}}=$ initial phenol concentration, $\mathrm{C}_{\mathrm{f}}=$ final phenol concentration

\subsection{Analytical procedures}

Enzyme activity of peroxidase was measured using a colorimetric assay containing phenol, 4-aminoantipyrene (4-AAP) and $\mathrm{H}_{2} \mathrm{O}_{2}$. This assay is a modification of that developed by $\mathrm{Wu}$ et al. [18] in which the assay mixture consists of $250 \mu \mathrm{L}$ of $9.6 \mathrm{mM} 4-\mathrm{AAP}, 100 \mu \mathrm{L}$ of $100 \mathrm{mM}$ phenol, $100 \mu \mathrm{L}$ of $2 \mathrm{mM} \mathrm{H}_{2} \mathrm{O}_{2}, 450-500 \mu \mathrm{L}$ of $100 \mathrm{mM}$ phosphate buffer ( $\mathrm{pH}$ 6.0) and $50-100 \mu \mathrm{L}$ of enzyme solution. Prior to significant substrate depletion, activity was proportional to the rate of formation of a coloured product which absorbs light at a peak wavelength of $510 \mathrm{~nm}$ with an extinction coefficient of $7100 \mathrm{~L} / \mathrm{mol} . \mathrm{cm}$ based on the conversion of $\mathrm{H}_{2} \mathrm{O}_{2}$. One unit of activity is defined as the number of micromoles of $\mathrm{H}_{2} \mathrm{O}_{2}$ consumed per minute at $\mathrm{pH} 6.0$ and $25^{\circ} \mathrm{C}$.

Phenol concentrations were determined colorimetrically using 4-AAP and potassium ferricyanide in an alkaline buffer medium. Phenolic compounds react with 4-AAP under alkaline conditions to yield an intermediate species which is oxidized in the presence of the potassium ferricyanide reagent. The resulting compound is a quinone-type dye which absorbs light at $510 \mathrm{~nm}$. The colour intensity is linear with respect to phenol concentration, provided that this concentration does not exceed $0.1 \mathrm{mM}$ in the cuvette [19]. The absorbance was measured at $510 \mathrm{~nm}$ after 5 minutes.

\section{Results and discussions}

\subsection{Enzyme activity of peroxidase}

The extracted crude enzymes from the skin peels of jicama and luffa exhibited similar enzyme activities, being $1.34 \mathrm{U} / \mathrm{mL}$ and $1.22 \mathrm{U} / \mathrm{mL}$ respectively. The crude extracts were used as produced without any further purification.

\subsection{Effect of $\mathrm{pH}$}

The effect of $\mathrm{pH}$ on phenol removal was conducted by using various buffer solutions ranging from $\mathrm{pH} 4$ to 9 at $25^{\circ} \mathrm{C}$. The buffer solutions used were acetate buffer $(\mathrm{pH} 4$ to 5), phosphate buffer ( $\mathrm{pH} 6$ to 7 ) and borate buffer ( $\mathrm{pH}$ 8 to 9 ). The dependence of phenol removal efficiency on $\mathrm{pH}$ is as shown in Fig. 1.

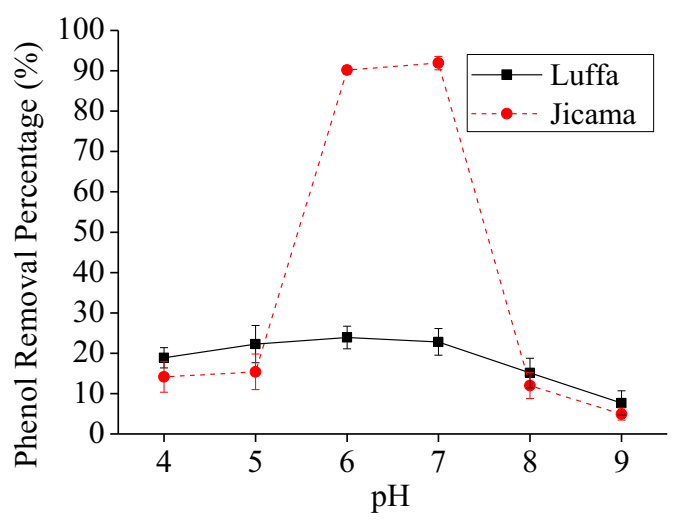

Figure 1. Effect of buffer $\mathrm{pH}$ on phenol removal (experiment conditions: $1.5 \mathrm{~mL}$ enzyme, $1 \mathrm{mM} \mathrm{H}_{2} \mathrm{O}_{2}$ at $25^{\circ} \mathrm{C}$ ).

When $1 \mathrm{mM}$ phenol solution was treated with jicama peroxidase, removal efficiency of approximately $90 \%$ was observed at $\mathrm{pH}$ values 6 to 7 , with the optimum occurring at $\mathrm{pH} 7$. Removal efficiency decreased to less than $20 \%$ below $\mathrm{pH} 5$ and above $\mathrm{pH}$ 8. This is a result of variations in enzyme protein structure in response to varying $\mathrm{pH}$. The enzyme molecules undergo structural modifications as a result of protonation and hydroxylation effects which could potentially obscure the enzyme active sites before causing denaturation and permanent loss of functionality. Moreover, the decrease in removal efficiency at $\mathrm{pH}$ above 8 could be attributed to the formation of phenol conjugated base since the $\mathrm{pK}_{\mathrm{a}}$ of phenol at $25^{\circ} \mathrm{C}$ is 10 . This conjugated basic form does not permit the phenolic compounds to act as hydrogen donors, thus hindering binding onto the surface of the enzyme active sites.

Luffa peroxidase, on the other hand, showed low phenol removal efficiency of less than $24 \%$ over the $\mathrm{pH}$ ranges being evaluated. Though enzyme activities of both luffa and jicama were similar as mentioned earlier, this finding suggested that luffa peroxidase might require higher concentration of $\mathrm{H}_{2} \mathrm{O}_{2}$ for oxidation of its enzyme into catalytically active form which is capable of reacting with phenolic compounds [20].

Previous studies on phenol removal catalyzed by horseradish peroxidase (HRP) demonstrated optimal operating $\mathrm{pH}$ at $\mathrm{pH} 8$ [12], which was slightly basic. Another work by Wright and Nicell [14] showed that nearly complete removal of phenol was observed over a $\mathrm{pH}$ range of 5 to 9 , with the maximum removal at $\mathrm{pH} 6$ by using high dose of soybean peroxidase (SBP). The optimum operating $\mathrm{pH}$ for jicama peroxidase was 
narrower than SBP, implying that it is more sensitive to $\mathrm{pH}$ change. All subsequent enzymatic reactions were conducted using phosphate buffer $\mathrm{pH} 7$.

\subsection{Effect of $\mathrm{H}_{2} \mathrm{O}_{2}$ concentration}

Enzymatic reaction cannot take place in the absence of $\mathrm{H}_{2} \mathrm{O}_{2} \cdot \mathrm{H}_{2} \mathrm{O}_{2}$ is required in peroxidase-catalyzed reactions to oxidize the native enzyme molecules (E) into Compound $\mathrm{I}\left(\mathrm{E}_{\mathrm{i}}\right)$ which then accepts an aromatic compound $\left(\mathrm{AH}_{2}\right)$ into its active site and carries out its oxidation to produce a free radical ( $\mathrm{AH})$. The free radical is released from the catalytic site leaving the enzyme as Compound II $\left(\mathrm{E}_{\mathrm{ii}}\right)$. Compound II oxidizes a second aromatic molecule, resulting in the release of a second free radical into the solution and returning the enzyme to its native state. The one-electron oxidation of aromatic substrate catalyzed by peroxidase is usually depicted by the following mechanism [21]:

$$
\begin{gathered}
\mathrm{E}+\mathrm{H}_{2} \mathrm{O}_{2} \rightarrow E_{i}+\mathrm{H}_{2} \mathrm{O} \\
E_{i}+\mathrm{AH}_{2} \rightarrow E_{i i}+{ }^{\bullet} \mathrm{AH} \\
E_{i i}+\mathrm{AH}_{2} \rightarrow \mathrm{E}+{ }^{\bullet} \mathrm{AH}+\mathrm{H}_{2} \mathrm{O}
\end{gathered}
$$

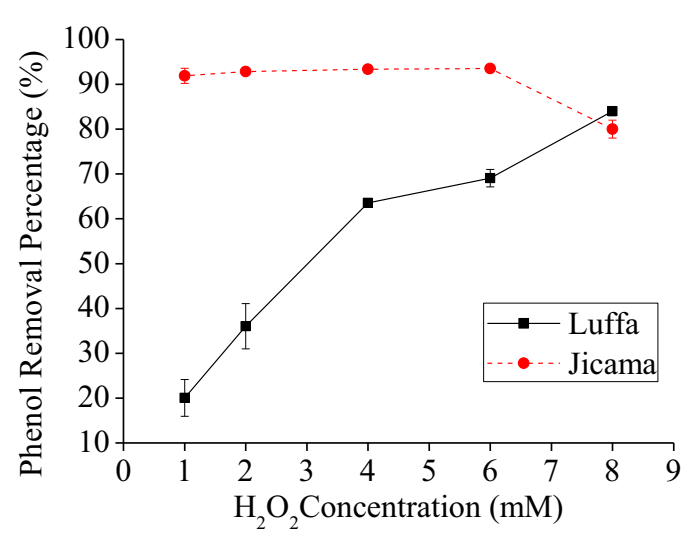

Figure 2. Effect of $\mathrm{H}_{2} \mathrm{O}_{2}$ concentration on phenol removal (experiment conditions: $1.5 \mathrm{~mL}$ enzyme, buffer $\mathrm{pH} 7$ at $25^{\circ} \mathrm{C}$ ).

The effect of various concentrations of $\mathrm{H}_{2} \mathrm{O}_{2}$ on phenol removal by jicama and luffa peroxidases is as illustrated in Fig. 2. Phenol removal efficiency of more than $90 \%$ was recorded by jicama peroxidase over a range of $\mathrm{H}_{2} \mathrm{O}_{2}$ concentrations from $1 \mathrm{mM}$ to $6 \mathrm{mM}$. When $\mathrm{H}_{2} \mathrm{O}_{2}$ concentration was further increased to $8 \mathrm{mM}$, there was a decrease of about $10 \%$ in removal percentage. This could be attributed to enzymatic inhibition effect caused by $\mathrm{H}_{2} \mathrm{O}_{2}$. High concentrations of $\mathrm{H}_{2} \mathrm{O}_{2}$ inhibit peroxidase catalytic activity by irreversibly oxidizing the enzyme ferriheme group which is vital for peroxidase catalysis [22].

A different trend was exhibited by luffa peroxidase in regards to $\mathrm{H}_{2} \mathrm{O}_{2}$ concentration. When $\mathrm{H}_{2} \mathrm{O}_{2}$ concentration was increased, phenol removal percentage also increased. For the range of $\mathrm{H}_{2} \mathrm{O}_{2}$ concentrations being studied, the highest phenol removal efficiency of $84 \%$ was observed at $8 \mathrm{mM}$. The reason that luffa peroxidase requires a much higher dosage of $\mathrm{H}_{2} \mathrm{O}_{2}$ for better performance in phenol removal could be due to the difference in the structure of its peroxidase molecules' active sites. The result obtained also suggested that luffa peroxidase is less susceptible to $\mathrm{H}_{2} \mathrm{O}_{2}$ inhibition, a phenomenon commonly suffered by peroxidase-catalyzed enzymatic method. Subsequent experiments for luffa and jicama peroxidases were conducted using $6 \mathrm{mM}$ and $1 \mathrm{mM} \mathrm{H}_{2} \mathrm{O}_{2}$ respectively.

\subsection{Effect of enzyme volume}

The effect of enzyme concentration on phenol removal is important as it has a significant bearing on the process economics. The effect of crude peroxidase dosage in phenol removal from aqueous solution was investigated for both jicama and luffa peroxidases under varying volumes of $1.5 \mathrm{~mL}$ to $4.5 \mathrm{~mL}$, as shown in Fig. 3 .

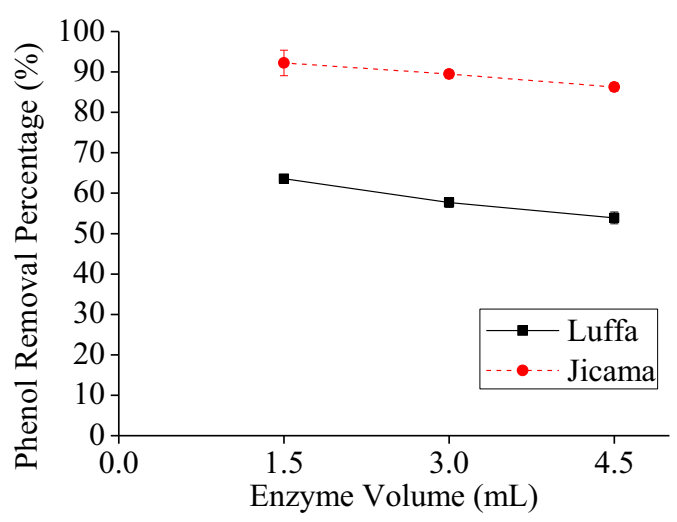

Figure 3. Effect of enzyme volume on phenol removal (experiment conditions: buffer $\mathrm{pH} 7,6 \mathrm{mM}$ and $1 \mathrm{mM} \mathrm{H}_{2} \mathrm{O}_{2}$ for luffa and jicama respectively at $25^{\circ} \mathrm{C}$ )

Both peroxidases exhibited similar trend, with removal efficiency decreasing when the enzyme volumes were increased. The efficiency of jicama peroxidase declined gradually from $92 \%$ at $1.5 \mathrm{~mL}$ enzyme volume to $86 \%$ at $4.5 \mathrm{~mL}$ enzyme volume. Luffa peroxidase showed a slightly higher drop, from $63 \%$ to $53 \%$ at $1.5 \mathrm{~mL}$ and $4.5 \mathrm{~mL}$ enzyme volume, respectively. Increase in enzyme volume means that there are greater amount of peroxidase molecules in the solution, and consequently increasing available active sites of enzyme for phenol binding. However, this scenario did not enhance the phenol removal efficiency as predicted. This could be a result of depletion and/or insufficient $\mathrm{H}_{2} \mathrm{O}_{2}$ under increasing concentration of enzyme. The heme prosthetic group of peroxidase reacts with $\mathrm{H}_{2} \mathrm{O}_{2}$ in the first step of the catalytic cycle, thus, under depleting levels of $\mathrm{H}_{2} \mathrm{O}_{2}$, this affects enzyme activation. A higher dosage of $\mathrm{H}_{2} \mathrm{O}_{2}$ might be required to activate both peroxidases at higher enzyme volumes.

\subsection{Effect of temperature}

The effect of temperature on phenol removal was examined by incubating the reaction mixtures at various temperatures, ranging from $25^{\circ} \mathrm{C}$ to $70^{\circ} \mathrm{C}$. As depicted in Fig. 4, jicama peroxidase attained a maximum phenol removal percentage of $92 \%$ at $25^{\circ} \mathrm{C}$ whereas luffa peroxidase showed a constant percentage averaging at $64 \%$. Elevated temperatures were found to demonstrate a 
significant adverse effect on jicama peroxidase as compared to luffa peroxidase. When the temperatures were increased from $25^{\circ} \mathrm{C}$ to $40^{\circ} \mathrm{C}$, jicama peroxidase suffered a drastic drop in removal efficiency from $92 \%$ to $41 \%$, which was more than half of the value. Its removal efficiency remained constant from $40^{\circ} \mathrm{C}$ to $60^{\circ} \mathrm{C}$. A slight decrease in removal efficiency was again observed when the temperature was further increased to $70^{\circ} \mathrm{C}$. Luffa peroxidase, however, is more stable towards thermal heat. Its activity can be preserved over a wider temperature range. This is shown by its nearly constant removal efficiencies over the range of $25^{\circ} \mathrm{C}$ to $70^{\circ} \mathrm{C}$. Higher temperatures neither enhance nor inhibit its activity in oxidizing phenol compounds.

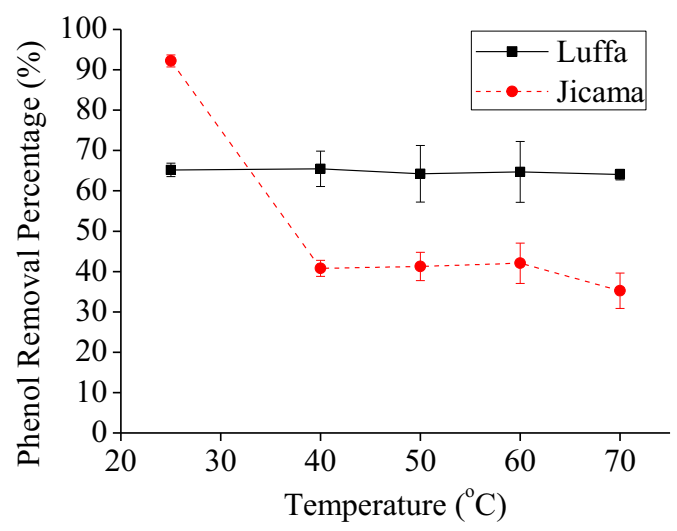

Figure 4. Effect of temperature on phenol removal (experiment conditions: $1.5 \mathrm{~mL}$ enzyme, buffer $\mathrm{pH} 7,6 \mathrm{mM}$ and $1 \mathrm{mM} \mathrm{H}_{2} \mathrm{O}_{2}$ for luffa and jicama respectively)

The decline in efficiency by jicama peroxidase could be attributed to thermal denaturation. Under elevated temperature conditions, thermal denaturation of enzyme molecules causes loss of its active sites in catalyzing substrate molecules. The thermal stability of peroxidases is governed by the haem prosthetic group, which is released under elevated temperatures to form apoenzyme. The transient enzyme formed is less stable and more susceptible to thermal inactivation as compared to the native enzyme [23]. Higher temperature conditions distort the structure of the enzyme, causing a limited binding capacity of its active sites onto substrate molecules. The optimum operating temperature for both jicama and luffa peroxidases was selected at $25^{\circ} \mathrm{C}$, in order to preserve peroxidase activities and save operating cost.

\section{Conclusions}

In the present study, both jicama and luffa peroxidases extracted from their respective fruit skin peels demonstrated promising performances in removing phenol from aqueous solution. Jicama peroxidase, though showing removal efficiency of about $90 \%$, has a narrow operating $\mathrm{pH}$ range and is more susceptible to thermal denaturation. Luffa peroxidase requires a much higher concentration of $\mathrm{H}_{2} \mathrm{O}_{2}$ to activate its active sites before it can carry out the oxidation of phenol. Its enzyme activity is also well preserved under the elevated temperatures being studied. The findings from this work revealed the potential of jicama and luffa peroxidases in the application of phenol removal. Nevertheless, a more comprehensive study such as optimization of the operating conditions might be necessary to better understand the factors affecting the performances of these peroxidases in phenol removal.

\section{References}

1. N. Caza, J. K. Bewtra, N. Biswas, K. E. Taylor, Water Res. 33, 3012 (1999)

2. A. Krastanov, Z. Alexieva, H. Yemendzhiev, Eng. Life Sci. 13, 76 (2013)

3. S. Mukherjee, S. Kumar, A. K. Misra, M. Fan, Chem. Eng. J. 129, 133 (2007)

4. K. Turhan, S. Uzman, Desalination 229, 257 (2008)

5. Y. Yavuz, A. Savas Koparal, Ü. Bakir Ögütveren, Chem. Eng. Technol. 30, 583 (2007)

6. T. T. Firozjaee, G. D. Najafpour, A. Asgari, M. Khavarpour, Chem. Ind. Chem. Eng. Q. 19, 173 (2012)

7. W. Gernjak, T. Krutzler, A. Glaser, S. Malato, J. Caceres, R. Bauer, et al., Chemosphere 50, 71 (2003)

8. G. Busca, S. Berardinelli, C. Resini, L. Arrighi, J. Hazard. Mater. 160, 265 (2008)

9. M. Gómez, M. D. Murcia, R. Dams, N. Christofi, E. Gómez, J. L. Gómez, Environ. Technol. 33, 1055 (2011)

10. A. M. Klibanov, B. N. Alberti, E. D. Morris, L. M. Felshin, J. Appl. Biochem. 2, 414 (1980)

11. M. Wagner, J. A. Nicell, Water Res. 35, 485 (2001)

12. J. A. Nicell, J. K. Bewtra, N. Biswas, C. C. St. Pierre, K. E. Taylor, Can. J. Civ. Eng. 20, 725 (1993)

13. S. Nakamoto, N. Machida, Water Res. 26, 49 (1992)

14. H. Wright, J. A. Nicell, Bioresour. Technol. 70, 69 (1999)

15. H. Ashraf, Q. Husain, Desalination 262, 267 (2010)

16. A. N. Deva, C. Arun, G. Arthanareeswaran, P. Sivashanmugam, J. Environ. Chem. Eng. 2, 1148 (2014)

17. J. Dec, J.-M. Bollag, Biotechnol. Bioeng. 44, 1132 (1994)

18. J. Wu, K. E. Taylor, J. K. Bewtra, N. Biswas, Water Res. 27, 1701 (1993)

19. M. Ghioureliotis, J. A. Nicell, Enzyme Microb. Technol. 25, 185 (1999)

20. M. Hamid, K. u. Rehman, Food Chem. 115, 1177 (2009)

21. J. A. Nicell, J. K. Bewtra, N. Biswas, E. Taylor, Water Res. 27, 1629 (1993)

22. M. A. Duarte-Vázquez, M. A. Ortega-Tovar, B. E. García-Almendarez, C. Regalado, J. Chem. Technol. Biotechnol. 78, 42 (2003)

23. J. P. McEldoon, J. S. Dordick, Biotechnol. Progr. 12, 555 (1996) 